\title{
Insight into Prison Camp Novels by Estonian Writers ${ }^{1}$
}

\author{
ANNELI KÕVAMEES
}

\begin{abstract}
The article focuses on the Estonian novels depicting Soviet prison camps in the 1940s and 1950s. For a long time the Soviet prison camp theme was not publicly discussed in Estonia due to political reasons. Texts dealing with prison camps could appear in print only outside the Soviet Union. The most notable of these are the novels by Arved Viirlaid. The Estonian prison camp novels can be seen as "the literature of testimony", to use the term by Leona Toker. Dramatic historical events are written down to record the events and to show the inhumane nature of the Soviet society. These records of the dramatic past follow certain patterns and create certain self- and heteroimages that are analysed in the article. The goal is to map themes, motifs and characteristics in such novels, concentrating on various taboos and rules in the prison camp environment. A prison camp is a closed territory within a closed territory; prison camps can be seen as small models of the Soviet society. Prison camp novels provide a detailed view of the environment of the prison camp, its inhabitants and activities. The lives of prisoners whirl around labour and food. The crucial thing is to survive, which often leads to moral decline, e.g. stealing or cheating. However, there are certain lines Estonians do not cross, e.g. cannibalism or homosexual relationships with superiors. Estonians are always depicted as political prisoners (not common criminals) and heterosexuals, while Russians are portrayed mainly as criminals and often also as homosexuals.
\end{abstract}

Keywords: prison camp literature; Gulag; Soviet system; Estonian prison camp novel

\section{Introduction}

The author of the history of the Soviet Gulag system Ann Applebaum has compared the repressive system of the Stalin era to a roulette: anyone could be arrested at any time for any reason (Applebaum 2005: 485). There were no clear criteria for the arrest and imprisonment in the Soviet Union like,

1 This research was supported by the Estonian Ministry of Education and Research (IUT 18-4), and by the European Union through the European Regional Development Fund (Centre of Excellence in Estonian Studies).

DOI: http://dx.doi.org/10.12697/IL.2016.21.2.12 
for example, in the national socialist Germany where the main criterion was based on race. "We were like rabbits [...] who recognised the right of the boa constrictor to swallow us" (Figes 2010: 280) has one of the detainees recalled the atmosphere of fear in the Soviet Union. The theoretical base for the terror was the doctrine of the Marxist class conflict and the destruction of the bourgeois class. Anybody could be called an enemy: those opposing the rulers or the groups of the population who might show even passive resistance to the regime (XX sajandi kroonika 2004: 425).

Prisoners served as cheap labour in the mines, construction sites and woods in Siberia and the Far North (ibid.); the labour of convicts was used on many big construction sites, for example, in the building of the Belomorkanal (White Sea Canal). The prison camp network stretched all over the Soviet Union. Gulag is the abbreviation from Glavnoje Upravlenije Lagerei (the Main Camp Administration) which besides its original meaning started to signify the Soviet "slavery system in all its forms: labour camps, penalty camps, the camps for criminals and political prisoners, women's camps, children's camps and transit camps" (Applebaum 2005: 11).

The predecessors of Gulag are found in Czarist Russia; the system as we know it today was formed after the Russian revolution (Applebaum 2005: 11). The number of prisoners increased in the 1930s during the arrests of the socalled kulaks ${ }^{2}$ (see e.g. Viola 2001, Viola 2007). The peak of the prison camp system was at the end of the 1940s and the beginning of the 1950s (XX sajandi kroonika 2004: 425). This is also the time when Estonians became acquainted with the Soviet prison camp system. Estonia lost its independence in 1940 when Soviet Russia occupied Estonia. The arresting and imprisonment began and continued during the second Soviet occupation which began in 1944. After Stalin's death in 1953, the reorganisation of the convict-labour camp system began, although camps did not disappear, since some of them were rearranged us prisons (Applebaum 2005: 13). Many prisoners had their cases re-examined after the death of Stalin, and many were released from prison.

While the survivors of the Nazi camps have had the chance to talk about their experience - there is a large number of books, documentaries and feature films, the survivors of the Soviet camps have been forced into silence for a long time. The wider audience learned about the Soviet prison camps in association with the works of Aleksandr Solzhenitsyn (1918-2008) whose The

2 Kulak: "(Russian: "fist"), in Russian and Soviet history, a wealthy or prosperous peasant, generally characterized as one who owned a relatively large farm and several head of cattle and horses and who was financially capable of employing hired labour and leasing land" (Encyclopredia Britannica 2013). 
Gulag Archipelago (1973) is fundamental. Both in the works of Solzhenitsyn and, for example, Varlam Shalamov (1907-1982), the author of Kolyma Tales (1970-1976), there are references to Fyodor Dostoyevsky (1821-1881) (see e.g. Galloway 2007; Peterson 2012, Mikhailik 2000) who has been called the founder of the prison camp novel as a literary genre (Morson s.a). Mostly, the prison camp works are based either on the author's personal experience or someone else's real-life experience, ${ }^{3}$ and the works of fiction are often taken as documentary historical literature. Fiction and factuality are mixed in the prison camp literature; even texts defined as novels or stories may, to a certain extent, comprise a documentary subject. For instance, in Solzhenitsyn's The Gulag Archipelago, newspaper reports, analytical commentaries, essays and testimonies, etc. can be found (Toker 2000: 112). Prison camp literature is characterised by "hybrid quality, seeming to be something more than fiction, yet something less than strict historiography" (Oja 1988: 111). Prison camp literature has been defined as a "literary text ${ }^{4}$ that describes or discusses the camp experience, no matter where or when written, or by whom, is a piece of camp literature; and one that does not is not" (Oja 1989: 272). Prison camp literature can be considered dissident literature (see e.g. Gruenwalt 1989). Officially and in propaganda, prison camps were exhibited as ideal social construction sites during the Stalin era, the gates of the camps "were decorated with the refrain from a popular song "Labour is a matter of honor, glory, courage, and heroism"” (Boym 2008: 343). Artists, writers and musicians were recruited to depict a utopian land "where men breathe most freely"s (Boym 2008: 343). To depict camps as a convict-labour hell meant to write against the ruling discourse; "camp literature is, by definition, a protest against the government's attempts to stifle debate as well as imprison people for thinking independently of the party" (Gruenwald 1989: 280). Prison camp literature also draws attention to human rights and describes the Soviet society without glorifying it; by writing that way it "is likely to lead [the author] to prison or camps" (Gruenwald 1987: 514).

In the quite voluminous textual corpus of prison camp literature memoirs dominate. The texts dealing with prison camps were published abroad as it was not possible to publish that kind of materials in the Soviet Union. Prison camp

\footnotetext{
3 A good example is the Eerik Horm-series by Estonian writer Arved Viirlaid. About the prototype of the novels see e.g. Grabbi 2007.

4 „By literary text I exclude secondary works of an obvious scholarly nature” (Oja 1989: 272-273).

5 The lines are from the song "Pesnia o rodine" ('Song of Our Motherland') by Isaak Dunaevskii (music) and Vassilii Lebedev-Kumach (lyrics) (Boym 2008: 343).
} 
literature is largely dissident literature; it allows to draw the West's attention to the problems in the Soviet Union. It is important to make one's voice to be heard, which may be reflected in the title (for example, I Speak for the Silent by Vladimir Tchernavin), but it is also essential to testify (Toker 2000: 74), to speak one's story and along with it the story of other survivors and victims. The term 'the literature of testimony' has been used to describe such writing (Toker 1997: 192). Certain structural patterns may be highlighted in the composition of the books dealing with prison camps: arrest, imprisonment, life in the prison camp and liberation. Most of the authors of prison camp literature are male, but there are some female writers, for example Evgenia Ginzburg whose Journey into the Whirlwind "doubles as a story of a former Communist's disillusionment and remorse" (Toker 2000: 52).

In the following, the article maps the structural patterns and motifs in the prison camp novels by Estonian authors, concentrating on the taboos and rules in the novels depicting Soviet prison camp experiences in the 1940s and 1950s. ${ }^{6}$ The article deals with the novels that concentrate on the prison camp life: Kes tappis Eerik Hormi? ('Who Killed Eerik Horm?', 1974), Surnud ei loe ('The Dead Do Not Read/The Dead Do Not Count', 1975), Märgitud ('The Marked', 1980), Vaim ja ahelad ('The Mind and Chains', 1961, revised edition 1998) by Arved Viirlaid (1922-2015); Varjud udus ('Shadows in the Fog', 1956) by Agu Kask (1906-1997); Kuradil ei ole varju ('The Devil Does Not Have a Shadow', 1979), Vägivallamaa ('The Land of Violence', 1982), Režiim - see kõlab uhkelt ('The Regime - It Sounds Wonderful', 1984) by Aili Helm;' Acheroni kaldal ('On the Shores of Acheron', 1991) by Albert Uustulnd (1925-1997); Põhjavalgus ('Northern Light', 2010) by Raimond Kaugver (1926-1992). The literature dealing with the life of the deportees in Siberia (for example, Maria Siberimaal ('Maria in Siberia', 1988) by Heino Kiik or Masendus ja lootus ('Depression and Hope', 1989) by Arvo Valton) is not under observation. All the novels that were investigated have been published abroad; in Estonia, the prison camp theme emerges only at the end of the 1980s (e.g. a collection of tales by Kaugver Kirjad laagrist ('Letters from the Camp', 1989)).

6 Imagology forms the theoretical basis for the article. About imagology see e.g. M. Beller, J. Leerssen, eds., Imagology. The Cultural Construction and Literary Representation of National Characters (2007).

7 Aili Helm is a pseudonym used by Helmut Tarand (1911-1987) and Hilja Rüütli (1921-2009). About the background see e.g. Lillemets 2011. 
KÕVAMEES

\section{Rules and Survival Strategies}

Most of the events in the prison camp novels take place in the closed camp territory. Usually, the depiction of the life in the prison camp is preceded by the arrest, interrogations, tortures and the depiction of the journey into the camp. Most of the novels finish with the liberation from the camp. A prison camp is a closed territory within a closed territory: the Soviet Union is excluded from the rest of the world and a prison camp is within that excluded territory surrounded by physical barriers: barbed wire, fence, and depending on the area, nature can also act as a barrier, which makes the escape hard or impossible. Overcoming the physical barriers does not mean freedom as one is liberated from the prison camp but enters the "bigger zone": the world outside the barbed wire does not mean freedom but a bigger (prison) zone, which is larger and less murderous than the prison camp but not more humane (Applebaum 2005: 23). It has been noted that even when being geographically outside the prison camp, "internally they never 'exit' from camp life" (Gullotta 2012: 82), and the prison camp experience will always follow the lives of the former convicts.

Prison camps can be seen as small models of the Soviet system where basically the same rules apply. Problems and depravities do not characterise only prison camps where these amplify but the Soviet system as a whole. "The prison or camp provides an opportunity for sociological as well as geographical exploration. Prisons, like armies, cut a slice through the social body, mixing people in unaccustomed ways" (McLean 1982: 258). Observing a prison camp one also observes the Soviet society. In prison camps, the lines between one's own people and foreigners, friends and enemies are clearer than in freedom: "when stepping outside the wire fence, one enters the real prison, the mental prison where you even spy after all your friends as if they were the cows of the $M V D !^{8}$ In the prison camp, where you are more or less naked, that nakedness serves actually as protection against suspicion and misunderstanding" (Viirlaid 1975: 148). ${ }^{9}$

Prison camp novels offer a detailed, even documental picture of the camp, its inhabitants, activities and environment. One of the most important components of the Estonians' auto-image is the differentiation between political and criminal prisoners. All the novels dealt with in this article show the world through the eyes of prisoners, not through the eyes of guards or other representatives of the system. The main characters are Estonians who

\footnotetext{
MVD: Министерство внутренних дем (Interior Ministry, Ministry of Home Affairs).

9 All the translations are the author's.
} 
are political prisoners sentenced to imprisonment because of their political beliefs and/or actions against the Soviet system, ${ }^{10}$ figthing in the German army or simply because of being somebody. It is said in Varjud udus that "the socalled Soviet justice and the court of law are not for administrating justice but only for convicting. And the convicted are those whom they want to convict" (Kask 1956: 222). This background and the differentiation between political prisoners and common criminals is important as it emphasises that Estonians are not simple criminals but victims of the Soviet system.

There are several us versus them oppositions in the basic structure of the novels. The most important of these is the opposition between political prisoners and common criminals who are mostly Russians. Both the world of political prisoners and the world of common criminals are depicted in the novels. The hierarchy and rules of the world of common criminals are described in detail. For example, the so-called honest thieves (the 'platnois') and 'sukas' are distinguished. Such thieves often settle their scores, and this is even favoured by the authorities as it helps to eliminate dangerous prisoners (see Viirlaid 1974: 83). "According to official Marxist doctrine, the common criminals, who come from the working class or peasantry, are a "socially close element", while politicals are presumably of bourgeois origin. This doctrine provided justification for allowing the common criminals [...] to terrorize and exploit the politicals with the acquiescence or active connivance of the authorities" (McLean 1982: 259). Common criminals were also favoured in amnesty (see e.g. Alexopoulos 2005: 275). Thus, another system within a closed prison camp system is formed. Common criminals form the prison elite, "being the favourites of the $\mathrm{NKVD}^{11}$ and the true rulers of the prison camp" (Viirlaid 1998: 128). They do not work, yet they are Stakhanovites ${ }^{12}$ who get additional portions of food (Viirlaid 1974: 110). The Estonian characters feel the injustice and resentment, and they draw conclusions about the Soviet society as a whole.

The most thorough overview of the subculture of common criminals is given in the novels Kes tappis Eerik Hormi? and Surnud ei loe by Viirlaid. The subculture of common criminals is described by an outsider; the relationships and rituals of the common criminals are seen as strange and disgusting (see e.g. Viirlaid 1974: 175-178). The nationality of common criminals is different

10 Usually the convictions were based on $\$ 58$ which included the so-called contra-revolutionary crimes (see Politilised arreteerimised Eestis 1996: B4-B5).

11 NKVD: Народный комиссариат внутренних дел (People's Commissariat of Internal Affairs).

12 Exceptionally hardworking and productive workers in the Soviet Union. 
from the main character; therefore, they are different in a double sense: they have a different nationality and different customs and behaviour. By defining the other, the us-group is also defined: we are everything they are not (e.g. humane and civilized), or we are nothing like they (e.g. inhumane, barbaric). The us-group is not strictly limited to Estonians, and the representatives of other nations can also be included. National identity is not the only collective identity, although for most it is the most important one (Firchow 1997: 34). Us-groups may also be formed based on religion, sexual orientation, political beliefs, etc. (Corbey, Leerssen 1991: viii).

Labour is a central topic in prison camp novels, and it fills most of the prisoners'day. Hard physical labour combined with poor food would quickly lead to fading unless tufta is used. It is a way to cheat the superiors, a custom which is not typical only of Gulag, but lies deep in the Soviet system as a whole (Applebaum 2005: 331). Various methods are used, which in the novels are quickly learned by the Estonians. For example, piles of wood are arranged in a new way, "which is a real magic as the piles of wood have to stand only as long as they are accepted [by the superintendent]" (Viirlaid 1975: 35), special marking techniques (Uustulnd 1991: 69) and calculation tricks are used (Kask 1956: 259), or the superior is simply bribed. In the world where everyone steals - prisoners, guards, superiors and people living outside prisons - it is not a big issue. Even the Estonians who at first find the Soviet rules unacceptable learn quickly as it is the only way to survive. When one has to choose between survival and high morals and beliefs, survival is chosen. In connection with that, an important component in the image of the Estonians is smartness and knowledge about how to swindle, which is opposed to the stupidity of the Russians. For example, in the novels by Helm, an important component is humour mixed with the feeling of superiority. Estonian researcher Oskar Loorits has found it to be characteristic of Estonians to make fun of their enemies and strangers (Loorits 1950: 6-7). In the novel Vägivallamaa there is a number of anecdotal stories about Russians and the Soviet system, e.g. the creation of the crematorium in Moscow (Helm 2009: 378). In the novel Režiim - see kõlab uhkelt a man called the nightingale of Kursk is portrayed. The man misuses foreign words not knowing their right meaning (Helm 2009: 400). Against the background of that kind of image of the Russians, the Estonians are depicted as educated and civilized, opposed to barbaric, uneducated and filthy Russians.

Better possibilities for survival and for coping with the life in the prison camp are offered by the pridurka-position (see Applebaum 2005: 342jj), which means a prisoner who has a better position than others. In the novels analysed in this article, only Helm uses the term (see Helm 2009: 222) although the 
majority of the Estonians in the prison camp novels have a privileged position. The Estonians quickly acquire the art of bribery, which enables them to get better jobs and thus escape the horrors of the common labour. Better positions are, for example, an accountant or various kinds of assisting or managing jobs, the artist of the prison camp, a hospital or a kitchen worker, etc. The Good Soldier Švejk type of events take place in the novel Acheroni kaldal where the Estonians manage to become convoy workers, which enables a wonderful life with good food and village girls. The main character also acts as a futurepredicting palmist which, on the one hand, characterises the enterprising spirit of the Estonians, while on the other, it depicts the credulity of the Russians.

A note from the doctor also allows to escape hard labour, but strict restrictions make it hard to get one. The system is based on norms which hold in every situation: "there was a fixed number of how many sick people were allowed to be released from work. When that number was full, even the dead on the earthen floor of the hut were considered as workers" (Viirlaid 1998: 118). While Estonians get a release from the doctor because they are skilful in deceiving the doctor, the common criminals do not care about their health (which for Estonians is most important) and use various harmful techniques to get the release. For example, they rub different substances into their eyes and as a result lose their eyesight or damage their hearing or viscera (Viirlaid 1974: 224).

\section{Taboos and Sexual Relationships}

In prison camp novels, aspects associated with the body are central. Prisoners are not masters of their own body as they are fed at certain times and their bodies are inspected in searching, etc. (McLean 1982: 261). Sexual relationships are also associated with the body and with various taboos in prison camp novels. Sexual relationships are also an important way of differentiating between foreigners and one's own people besides the opposition between common criminals and political prisoners.

Certain sexual relationships may be seen as a survival strategy which means choosing between moral decline and death. By having a sexual relationship with a person who has a higher position, it is possible to obtain a privileged position. This applies primarily to women. For example, the female character in the novel Vägivallamaa has an opportunity to become the so-called wife of the superior, but she declines the offer. The female characters by Helm are characterised by high morals and a strong sense of superiority. The Estonian woman sees herself as an educated lady who is surrounded by uneducated 
Russian louts. Estonian researcher Linda Kaljundi has raised the question of selectivity about what is spoken and what is left unspoken: "On the one hand, dealing with the issue of war and violence experiences of women means breaking taboos. On the other hand, the deportation and imprisonment memories of Estonian women are dominated by certain codes and a belief 'in things that are not spoken about'” (Kaljundi 2009). The novels by Helm are written according to the written and unwritten rules and according to the fixed image of the Estonian woman. The novels are written from the point of view of women, and there is no violence and capitulation to be found. The novel Põhjavalgus by Kaugver, on the other hand, depicts without illusions the condition of women in prison camps. Karin, a character in the novel, is forced to take the position of the so-called wife of the superior after repeated rapes and other horrors. She does not take the position willingly, as Russian women do; her physical purity may get smeared but mentally she remains different from the Russian women who take sexual relationships pragmatically and naturalistically. This fact is illustrated by a Russian woman called Olga who sees her body first and foremost as a piece of merchandise which must be sold at the highest possible price (Kaugver 2010: 226). It is important to notice in Olga's case the influence of the moulding role of the society. Olga herself expresses this fact in the dialogue with an Estonian man named Tiit who is the doctor of the prison hospital: "You were born at home, while I was born in the dormitory behind the screen. You eat to enjoy, while I and others like me eat to survive" (Kaugver 2010: 226). The Russian character in this novel is not negative only because she is Russian, but the criticism is directed towards the society, which moulds people with that kind of mentality. The system is seen as inhumane and demonic, aiming at destroying everything humane: "This is the victory of communism over the human spirit - to take the faith and hope from the individual, to destroy their will to live. To turn them into rags so that they lose even he perspectives of who they once were. Human understanding and beliefs are smashed [...]" (Viirlaid 1974: 236). The system favours the breaking of moral norms, and thus intimacy is exploited for the benefit of the society by both the individuals and the state. The most conspicuous examples are twin-prisons, prisons with male and female convicts, where "young and vital common criminals were chosen, whose most importan production was to increase the Russian population in the post-war years" (Viirlaid 1975: 137). The Estonians comment with a grin that this is also Stakhanovism (ibid.).

Men also have the opportunity to benefit from sexual relationships. One of the biggest taboos in prison camp novels is associated with homosexual relationships. Based on the novels analysed in this article, it can be said that Arved Viirlaid has examined this issue more thoroughly. In the novel Vaim ja 
ahelad, an Estonian man is offered benefits for sexual services, but the offer is firmly turned down (Viirlaid 1998: 102). For the Estonian characters that kind of relations are unacceptable, although the relationships between a man and a woman are not. For example, in Kes tappis Eerik Hormi? a young man named Uno talks about his adventures with the inhabitants of the prison camp for women (Viirlaid 1974: 140).

Kes tappis Eerik Hormi? offers the most thorough insight into the topic. The world of homosexual relationships with its rules and customs is disclosed. An important role is played by special tattoos, which besides marking belonging to a certain group, are strongly associated with sexuality (Viirlaid 1974: 85). The novels dealt with in this article can be analysed by using the works of Adi Kunstman who has studied (homo)sexuality in prison camp literature. The researcher has drawn attention to the fact that the homosexual relations of criminals and the criminals themselves are depicted as explicitly and repulsively sexual (Kuntsman 2008: 273) ${ }^{13}$, while the political prisoners are depicted as heterosexual (Kuntsman 2009: 309). Thus, the border between common criminals and political prisoners is tightly fixed. Besides nationality, sexuality is another way of forming the us-group, us-identity: us, the political prisoners and heterosexuals, $v s$. them, the common criminals and homosexuals. By adding the national component, the result is the following: Estonian heterosexual political prisoners and Russian homosexual common criminals.

The homosexuals are described using bestial terms; ${ }^{14}$ they "are located outside the human world" (Kuntsman 2009: 312). Those who belong to the ingroup are described using humane terms, while those outside are left the status of inferior semi-humans (Corbey, Leerssen 1991: vi). Homosexuals are outside the acceptable and are thus placed into the world of animals. "The criminals are associated with unruly, bestial sex and orgies; they do not experience moral dilemmas, on the contrary, they produce them (it is they who create the conditions for prostitution)" (Kuntsman 2009: 319). Others, political prisoners but also more passive criminals, constantly feel threatened, and the disgust towards homosexuals is "always haunted by fear" (Kuntsman 2008: 275).

Besides sexuality, food is also associated with various taboos. Food is stolen, hidden, exchanged, bought and sold. Frozen potatoes, thin soup and

13 For example in the works of Russian female authors only single homosexual contacts between political prisoners are mentioned and in these rare occasions the discreet nature of this relationships is emphasised (Kuntsman 2009: 313-314).

14 In fact the heterosexual relations of Russians are also described as bestial, see e.g. Kaugver 2010: 258, 275. The characters are often described using comparisons with animals, see e.g. Kaugver 2010: 238. 
soggy bread are inseparable attributes in prison camp novels. The survival depends on the skills to obtain and consume food. Food (and tobacco) is the best currency with which one can buy anything (Viirlaid 1998: 120), and the only way to protest efficiently in a prison camp is by a hunger strike (Viirlaid 1975: 86). The attitude towards food marks different groups and characters. The food practises of common criminals are seen as strange; in some cases their habits are described in naturalistic detail, for example rumination: “[...] to alleviate the torment caused by hunger, poor food was forced from the stomach back into the mouth to be chewed again. [...] Mouthfuls come back to the mouth effortlessly and peacefully like in beasts. The smell of vomit hovers above their heads" (Viirlaid 1974: 167).

The life in prison camps revolves around food, and every survival method is acceptable, but for Estonians there are limits that are unacceptable to cross. Life in a prison camp is a constant battle between preserving one's humanity and becoming an animal. The attitude towards food also separates nations. For example, Estonians help each other and share food. Sharing food and eating are associated with certain meanings (see e.g. Viirlaid 1998: 144). While Estonians share food because of their national solidarity, among common criminals the sharing of food brings ties that are unacceptable for Estonians. In the prison environment, nearly every aspect of life is associated with certain rules and rituals, and breaking those may have a fatal result.

Like sexuality, food is associated with various taboos and social (unwritten) rules that regulate human behaviour and define the in-group (Meyer-Rochow 2009). The Estonians do not overstep sexual taboos, but they sometimes overcome taboos associated with food. Most of the food taboos are related to the meat of different animals. To survive, people are ready to eat dog meat (Viirlaid 1974: 118) or raven meat (Viirlaid 1980: 189), but the ultimate taboo - cannibalism - stays strong for the Estonian political prisoners but not for the Russian prisoners. It is described with disgust and remorse how a human corpse is chopped into pieces and eaten (Viirlaid 1974: 120). In the novel, the victim is a Finnish man, which deepens the vexation of the Estonians. Nevertheless, in the novels analysed in this article there are no examples of the extreme cases of cannibalism - escaping with "mobile food", i.e. escaping with a fellow prisoner who will be eaten later (Applebaum 2005: 373).${ }^{15}$ In prison camp novels, an essential aspect is to stay human even though previous values may be re-evaluated. In the name of survival one is forced to do various things which would be unthinkable in freedom (e.g. to steal), but Estonian characters

15 About the Stalin era cannibalism see e.g. Várdy 2007. 
Insight into Prison Camp Novels by Estonian Writers

remain human, they do not become animals - a change that happens to many Russians who have been depicted as being barbarous and beastly.

\section{Conclusion}

In the centre of the novels depicting the Soviet prison camp experiences in the 1940s and 1950s are the horrors of the prison camp, its rules and survival. Simultaneously, the story of people is told, which can be taken as a story of one Estonian generation. The novels describe dramatic events and show the inhuman nature of the Soviet system. In the situation where Estonia was occupied and the world's knowledge about the prisons and prison camps of the Soviet Union was incomplete, one goal of the prison camp literature was to inform people about these dramatic events. Through the form of fiction, history is written and recorded into the so-called soft memory, which consists primarily of texts (see Etkind 2009: 194).

In the texts, the events are not only described and recorded, but certain patterns are used and certain auto- and hetero-images are created. In the novels, various oppositions play an important role, for example, we - the Estonians, they - the Russians. In this way the positive image of Estonians is fixed (educated, cultural, European) as opposed to the negative image of the Russians (uneducated, uncultured, barbarous, and non-European). Specifically, the distinction between the Estonians as political prisoners and the Russians as common criminals is added.

Among the novels analysed in this article, Arved Viirlaid is the writer who mainly addresses the issue of homosexuality, which is one of the biggest taboos in prison camp literature. While heterosexual relationships are dealt with in most of the novels, homosexual relationships are more thoroughly discussed only in the novels by Viirlaid, most notably in Kes tappis Eerik Hormi?. In this novel, a clear differentiating pattern is visible: political prisoners are depicted as heterosexuals, while homosexuality is found between common criminals whose behaviour is described as bestial and barbarous. Therefore, negative attributes are used to describe Russian characters. There are some novels where a slightly superior and ridiculing tone is used, for example, in the novels by Aili Helm. The social-historical background has activated old images; in the prison camp context, the Russians are not associated with their rich cultural heritage but with the negative side of the Russian image (see Naarden, Leerssen 2007: 228). Thus, in the context of prison camp horrors the Ivan the Terrible type arises. It is important to note that the nationality is not seen as the reason; an essential role is played by the Soviet system which moulds the 
KÕVAMEES

actions and thinking of people. The criticism of the system is vital both in the novels by Estonian writers and in prison camp literature in general. In the case of Estonia, a national dimension is added as the Soviet person is in most cases equated with being Russian. This is also the case in memoirs, which could be the next subject to analyse.

\author{
Anneli Kõvamees \\ anneli.kovamees@tlu.ee \\ Tallinna Ülikool \\ Humanitaarteaduste instituut \\ Narva mnt 29 \\ 10120 Tallinn \\ EESTI / ESTONIA
}

\title{
References
}

Alexopoulos, G. 2005. Amnesty 1945. The Revolving Door of Stalin's Gulag. - Slavic Review, Vol. 64, No. 2, 274-306.

Applebaum, A. 2005. Gulag. Nõukogude koonduslaagrite ajalugu. Tallinn: Varrak.

Boym, S. 2008. "Banality of Evil", Mimicry, and the Soviet Subject. Varlam Shalamov and Hannah Arendt. - Slavic Review, Vol. 67, No. 2, 342-363.

Corbey, R., Leerssen, J. 1991. Studying Alterity. Backgrounds and Perspectives. R. Corbey, J. Leerssen, eds., Alterity, Identity, Image. Selves and Others in Society and Scholarship. (Amsterdam Studies on Cultural Identity, No. 1). Amsterdam, Atlanta: Rodopi, vi-xviii.

Encyclopædia Britannica 2013 = Kulak. - Encyclopedia Britannica. Encyclopredia Britannica Ultimate Reference Suite. Chicago: Encyclopædia Britannica.

Etkind, A. 2009. Post-Soviet Hauntology. Cultural Memory of the Soviet Terror. Constellations, Vol. 16, No. 1, 182-200.

Figes, O. 2010. Sosistajad. Eraelu Stalini Venemaal. Tallinn: Varrak.

Firchow, P. E. 1997. National Stereotypes in Literature. A Critical Overview. M. Beller, ed., L'immagine dell'altro e l'identità nazionale: metodi di ricerca letteraria. Fasano di Brindisi: Schena, 33-40.

Galloway, D. J. 2007. Polemical Allusions in Russian Gulag Prose. - The Slavic and East European Journal, Vol. 51, No. 3, 535-552.

Grabbi, H. 2007. Eerik Heine saaga ja Arved Viirlaiu romaanid. - Looming, 1, 112-124.

Gruenwald, O. 1987. Yugoslav Camp Literature. Rediscovering the Ghost of a Nation's Past-Present-Future. - Slavic Review, Vol. 46, No. 3/4, 513-528.

Gruenwald, O. 1989. Response: Camp Literature: Archetype for Dissent. - Slavic Review, Vol. 48, No. 2, 280-283.

Gullotta, A. 2012. Trauma and Self in the Soviet Context: Remarks on Gulag Writings. - AvtobiografЯ, No. 1, 73-87. 
Helm, A. 2009. Kuradil ei ole varju. Vägivallamaa. Režiim - see kõlab uhkelt. Tallinn: Eesti Päevaleht, Akadeemia.

Kaljundi, L. 2009. Eesti lugu: Aili Helm „Kuradil ei ole varju“. - Eesti Päevaleht, 8.05 http://www.epl.ee/artikkel/467937 (2.07.2012).

Kask, A. 1956. Varjud udus. Lund: Eesti Kirjanike Kooperatiiv.

Kaugver, R. 2010. Põhjavalgus. Tallinn: Pegasus.

Kuntsman, A. 2008. Between Gulags and Pride Parades. Sexuality, Nation, and Haunted Speech Acts. - GLQ: A Journal on Lesbian and Gay Studies, Vol. 14, No. $2-3,263-287$.

Kuntsman, A. 2009. "With a Shade of Disgust": Affective Politics of Sexuality and Class in Memoirs of the Stalinist Gulag. - Slavic Review, Vol. 68, No. 2, 308-328.

Lillemets, E. 2011. Kust võtta niisugust enesevalitsust, mis oleks tugevam kui Vene valitsus? Aili Helmi esmailmumise puhul Eestis. - Looming, 9, 1284-1296.

Loorits, O. 1950. Okupatsioon rahvapilke kõverpeeglis. Stockholm: Tõrvik.

McLean, H. 1982. Walls and Wire. Notes on the Prison Theme in Russian Literature. - International Journal of Slavic Linguistics and Poetics, XXV/XXVI, 254-265.

Meyer-Rochow, V. B. 2009. Food taboos. Their Origins and Purposes. - Journal of Ethnobiology and Ethnomedicine, Vol. 5 http://www.ethnobiomed.com/content/ 5/1/18\# (19.03.2013).

Mikhailik, E. 2000. Dostoevsky and Shalamov. Orpheus and Pluto http://shalamov. $\mathrm{ru} / \mathrm{en} / \mathrm{research} / 122 /(2.07 .2012)$

Morson, G. S. s.a. Fyodor Dostoyevsky. - Encyclopredia Britannica. http://www. britannica.com/EBchecked/topic/169765/Fyodor-Dostoyevsky/59061/TheBrothers-Karamazov (12.08.2013).

Naarden, B., Leerssen, J. 2007. Russians. - M. Beller, J. Leerssen, eds., Imagology. The Cultural Construction and Literary Representation of National Characters. Amsterdam - New York: Rodopi, 226-229.

Oja, M. F. 1988. Fictional History and Historical Fiction. Solzhenitsyn and Kiš as Exemplars. - History and Theory, Vol. 27, No. 2, 111-124.

Oja, M. F. 1989. Toward a Definition of Camp Literature. - Slavic Review, Vol. 48, No. 2, 272-274.

Peterson, L. 2012. The Development of Labor Camp Literature. A Cultural Analysis of the House of the Dead and the Gulag Archipelago. - Honors Theses. Paper 67. http://diginole.lib.fsu.edu/uhm/67 (2.07.2012).

Poliitilised arreteerimised Eestis $1996=\mathrm{L}$. Õispuu, ed., Poliitilised arreteerimised Eestis 1940-1988 (\$58). 1. kd. Tallinn: Eesti Represseeritute Registri Büroo.

Toker, L. 1997. Toward a Poetics of Documentary Prose - From the Perspective of Gulag Testimonies. - PoeticsToday, Vol. 18, No. 2, 187-222.

Toker, L. 2000. Return from the Archipelago. Narratives of Gulag Survivors. Bloomington, Indianapolis: Indiana University Press.

Uustulnd, A. 1991. Acheroni kaldal. Tallinn: Eesti Raamat.

Várdy 2007 = Várdy, S. B., Várdy, A. H. 2007. Cannibalism in Stalin's Russia and Mao’s China. - Eastern European Quarterly XLI, No. 2, 223-238.

Viirlaid, A. 1974. Kes tappis Eerik Hormi? Lund: Eesti Kirjanike Kooperatiiv. 
KÕVAMEES

Viirlaid, A. 1975. Surnud ei loe. Lund: Eesti Kirjanike Kooperatiiv.

Viirlaid, A. 1980. Märgitud. Lund: Eesti Kirjanike Kooperatiiv.

Viirlaid, A. 1998. Vaim ja ahelad. Tallinn: Virgela.

Viola, L. 2001. The Other Archipelago. Kulak Deportations to the North in 1930. Slavic Review, Vol. 60, No. 4, 730-755.

Viola, L. 2007. The Unknown Gulag. The Lost World of Stalin's Special Settlements. New York, Oxford: Oxford University Press.

XX sajandi kroonika $2004=$ XX sajandi kroonika. Eesti ja maailm. 2. osa. Tallinn: Eesti Entsüklopeediakirjastus. 